ers. Lack of copyright protection facilitated the profusion of French works in the United States, and publishers of texts with provocative titles like Michelet's could sell twenty thousand copies in the first month. Michelet provoked both admiration and criticism when he advanced the idea that women were invalids physiologically, but exalted by their spiritual power. His Du prêtre, de la femme et de la famille, translated as Spiritual Direction and Auricular Confession in 1845, took on a decidedly anti-Catholic cast when it pitted the Catholic confessor as a rival for authority with the male head of the household. During dinner conversations, the priest's invisible, regressive presence was blamed for preventing wife and daughters from embracing the patriarch's progressive views.

Michelet's ideas contributed to a cult of domesticity that held that women's natural sentiments of love, sympathy, and compassion were best cultivated in the tranquility of the domestic sphere. The convent was imagined to be diametrically opposed to that sphere, and few incidents created a greater international outcry than that of Sister Barbara Ubryk, a nun held captive, naked, shivering, and covered with excrement in a convent in Cracow in 1869. Verhoeven brilliantly analyzes the parallels between the convent atrocity genre, so familiar in France, and the Indian captivity genre in the United States, and explains why both resonated so powerfully. He notes how Ubryk's story bolstered the cult of domesticity and the power of patriarchy by underscoring the humiliation and deprivation that women experienced in convents and the dangers that they faced in the outside world.

There are many dimensions to the transnational exchange of antiCatholic ideas, including the opportunities that people on both sides of the Atlantic took to reflect upon French or American exceptionalism. Verhoeven's genius is in revealing how anti-Catholic literature voiced fears both about encroachments on men's freedom in the political sphere and about encroachments on their privilege in the home. Within this book, with its straightforward title and modest format, lie treasures of insight and detail that exceed the scope of this short review.

Lindsay Wilson

Northern Arizona University

\title{
Tiqqun. This is not a Program, trans. Joshua David Jordan (Cambridge: Semiotext, 2011).
}

This is not a Program consists of two essays: "This is Not a Program" and "A Critical Metaphysics Could Emerge As a Science of Apparatuses." Although the two works address distinct issues, they both aim to draw conclusions from the failure of the revolutionary left. This Is Not a Program is not and does not claim 
to be a piece of scholarly work. The two essays originally appeared in 2001 in the second issue of Tiqqun, a short-lived journal whose name has also been used as a collective pseudonym for a group of French radical activists. Some of Tiqqun's essays were later reprinted by La Fabrique, an independent company known for having published The Coming Insurrection. The latter, an anonymous pamphlet calling for "all power to the communes," received some publicity in November 2008 when Julien Coupat, one of the founders of Tiqqun, was charged for allegedly sabotaging the overhead wires of a French train line (Comité Invisible, 123).

Unlike The Coming Insurrection, Tiqqun's essays require background knowledge of Italian history since 1968, Marxist theory, Foucaultian theory and one of the author's other works: Theory of Bloom. The first, eponymous essay mainly consists of a status report on the "ultra-left" today (13, 23). In Tiqqun's opinion, only a part of what he calls the "Imaginary Party" is truly anti-imperialistic. Unfortunately, Tiqqun does not provide a clear definition of the Imaginary Party. In general, the author seems to understand it as synonymous with the "New Left" (26).

As for the concept of "Empire," so central to the essay, the reader has to pay close attention to the labyrinthine structure of the analysis in order to understand the author's definition of it. It is possible, however, to piece together an idea of what Tiqqun means by Empire. Inspired by Michel Foucault's notion of biopower, the author states that " $\mathrm{t}]$ he unique thing about Empire is that it has expanded its colonization over the whole of existence and over all that exists" (66). Empire thus comprises all officially sanctioned economic, social, political, and cultural institutions and organisations (including political parties and unions). As a result, anyone wanting to escape the influence of Empire must refuse to enter into its logic. The purpose of the radical segments of the Imaginary Party should then consist in going under the radar of Empire at all costs.

Tiqqun's stance explains his rejection of Antonio Negri’s views. By attempting to fight Empire with its own weapons and networks, the Negrists have only succeeded in becoming "the idealist face of imperial thought" (118). Tiqqun thus advocates a return to the Foucaultian sources, implicitly presenting the concept of biopower as adequately describing the nature of Empire in our day and age. Since " $[\mathrm{m}]$ ilitancy and its critique are both in different ways compatible with Empire, one as a form of work, the other as a form of powerlessness" (132), the only solution lies in a complete refusal of the system, a multiform armed struggle.

To illustrate what he means by armed struggle, Tiqqun uses 1970s Italy as a case study. Unfortunately, his philosophical analysis makes it difficult to distinguish digressions from the core of the argument. Although readers knowledge- 
able about the "Years of Led" might be able to make sense of this part of the argument, many will be discouraged by the author's arcane references to splinter groups within the Red Brigades (19-20, 47-82) and the involvement of the P2 Lodge in Italian politics $(22,99)$.

The second essay explores an aspect of Empire called "apparatuses." Apparatuses are existential devices meant to keep human beings dependent on Empire. They come in various forms, either concrete or abstract, such as "a cell phone, a sedative, a shrink, a lover, a movie - all make for decent crutches provided they can be changed up often enough" (149). Tiqqun analyses those apparatuses from the viewpoint of the "Theory of Bloom," defined as "[a]n attempt to historicize presence, to record, for starters, the current state of our being-inthe-world" (143). Apparatuses are related to the concept of Bloom in that the latter assesses the degree of dehumanisation.

Unlike the previous essay, "A Critical Metaphysics..." is meant to be a programme or, rather, "the founding act of S.A.C.S., the Society for the advancement of Criminal Science... whose mission is to anonymously collect, classify, and share all knowledge-powers that may be of use to anti-imperial war machines" (135). Though more self-referential than "This is Not a Program," this essay will be more accessible to readers familiar with Heidegger's concept of Dasein and Marxist alienation theory.

As a whole, the book is immensely frustrating. At several points in the text one expects to learn that Foucault stood Marx on his head just as Marx did Hegel. This argument, however, remains buried under the book's chaotic structure, as if the author wanted to leave one sacred cow untouched. Nevertheless, despite its lack of formal and conceptual clarity, This Is Not a Program is worth reading. Although its value certainly lies not in its capacity to break new scholarly ground, it is a primary document in the making, a source that historians of the European left will find symptomatic of the early twenty-first century. Underneath its murky surface, Tiqqun's book speaks for an orphaned generation of leftists looking for alternatives to classical Marxism and to a rusty New Left.

Finally, the translation is brilliant and must have constituted a daunting task. Although Jordan's choice to translate the French pronoun "on" by "THEY" is problematic from a grammatical point of view, the successful adaptation into English of Tiqqun's language and style is in itself quite a feat. However, more explanatory notes and a preface would have made this translation more accessible to neophytes. 